\title{
CERTAIN RELATIONS BETWEEN THE PARATHYROIDS, THE HYPOPHYSIS AND THE PANGREAS*
}

\author{
BY BERNARDO A. HOUSSAY, M.D. $\dagger$
}

$\mathbf{T}$ HE present paper will deal only with the manner in which the hypophysis and the pancreas can influence the structure and function of the parathyroids, rather than attempt to consider all of the many relationships which may exist between these glands or their secretory products. It may be noted here that the parathyroids, due to their small size, are frequently overlooked in postmortem examinations; also the microscopical alterations may be passed by, as frequently they are not easy to interpret. These facts explain to a certain extent why the histophysiology of these glands is less well known than that of others.

In 1930 Lascano Gonzalez, in our Institute, found pronounced lesions in the parathyroids of dogs whose pituitary and pancreas had been removed. ${ }^{3 i, 38,42}$ This finding led us to study the microscopical aspect of the parathyroids and also the blood calcium of (a) hypophysectomized, (b) pancreatectomized and (c) hypophysectomized-pancreatectomized dogs.

THE PARATHYROIDS IN PITUITARY INSUFFICIENCY Morphology. The development and the maintenance of the normal structure and function of the endocrine glands (thyroids, gonads, adrenal cortex, parathyroids, thymus, etc.) are conditioned by the anterior pituitary, and hypophysectomy results in abnormal changes. In the case of the parathyroids hypophysectomy is followed by regressive lesions which can be seen microscopically, but it is difficult to determine whether the total mass of parathyroid tissue is reduced. Smith ${ }^{79}$ found a diminution of the total amount of epithelial bodies in hypophysectomized tadpoles, but apparently there was no marked alteration in their structure. Smith ${ }^{73}$ stated that atrophy of the parathyroids occurred in hypophysectomized rats, but in a later paper ${ }^{80}$ he did not mention this condition, and Collip ${ }^{18}$ was unable to confirm the observation. In the subtotally hypophysectomized hen no modifications have been found $;^{61}$ and in the hypophysectomized rabbit there are only slight changes, mainly a decrease in the size of the cells. ${ }^{85}$ Livon and Peyron, ${ }^{53}$ Aschner, ${ }^{4}$ and Collip, ${ }^{18}$ saw no changes in the parathyroids of hypophysectomized dogs; on the other hand Koster and Geesink $^{47}$ mention having found these glands atrophied, but give no further data on this subject.

We have been unable to find any reports on *Harvey Lecture delivered at the New York Academy of Medicine, January 16, 1936 .

†Houssay, Bernardo A.-Professor of Physiology, Faculty of Medical Sciences, University of Buenos Aires, 1919-. For record and address of author see "This Week's Issue," page 946, issue of May 7. the structure of the parathyroids in human cases of pituitary insufficiency.

Lesions of the parathyroids have been reported in several papers published from our Institute since 1930. Up to date these glands have been examined in forty-two normal dogs, forty-six hypophysectomized, three hypophysectomized-thyroidectomized and in sixteen with lesions of the tuber cinereum.

The parathyroids of the normal, craniotomized controls have a massive, reticular or lobulated structure. The cells are polygonal or globulous and the majority have a clear or only slightly granular protoplasm. In some glands, especially near the surface, groups of dark staining nuclei are found so closely packed together that no protoplasm can be seen around them (Syncitium-ähnliche Zellgrupen). The connective tissue is searce and in it are seen very fine blood vessels.

The first alterations occurring in the parathyroids of hypophysectomized dogs consist of the following phenomena: the cells decrease in size; the protoplasm becomes dark and granular, and its borders are no longer clearly marked; the nuclei are also reduced in size and the cells are more closely packed, so that they separate from the connective tissue stroma. This gives the structure of the gland a trabecular or cord-like aspect. Later the protoplasm atrophies and finally disappears almost completely, leaving the nuclei in rows or heaps. It is important to note that these modifications are found only in certain parts of the gland, e.g., at one of its poles or sides. In the most advanced degree the protoplasm disappears and only rows of nuclei are left, the meshes of the connective tissue stroma become prominent, and the blood vessels are dilated and sometimes surrounded by a fibrous sheath. In parts of the gland the degeneration of the epithelial cells may be so complete that acellular structureless zones of irregular dimensions and of granular aspect are formed; these stain a rosy violet color.

These alterations are not uniformly distributed, so that in any one animal some of the glands may be almost normal while others may show severe lesions. In the same gland normal and modified regions are to be found side by side. The morphological changes first appear five to fourteen days after hypophysectomy; they then spread and finally become stabilized. The following degrees may be differentiated (figure 1):

(a) Slight: uniform cellular atrophy, few groups of closely packed nuclei, trabecular structure. (Figure 2A.) 

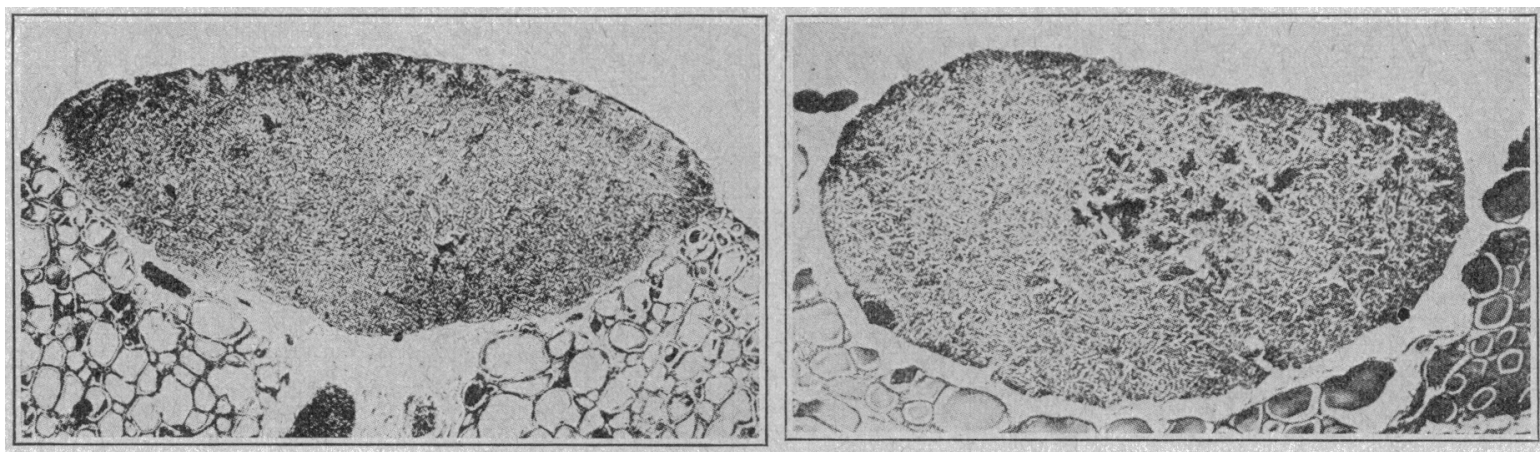

A

B
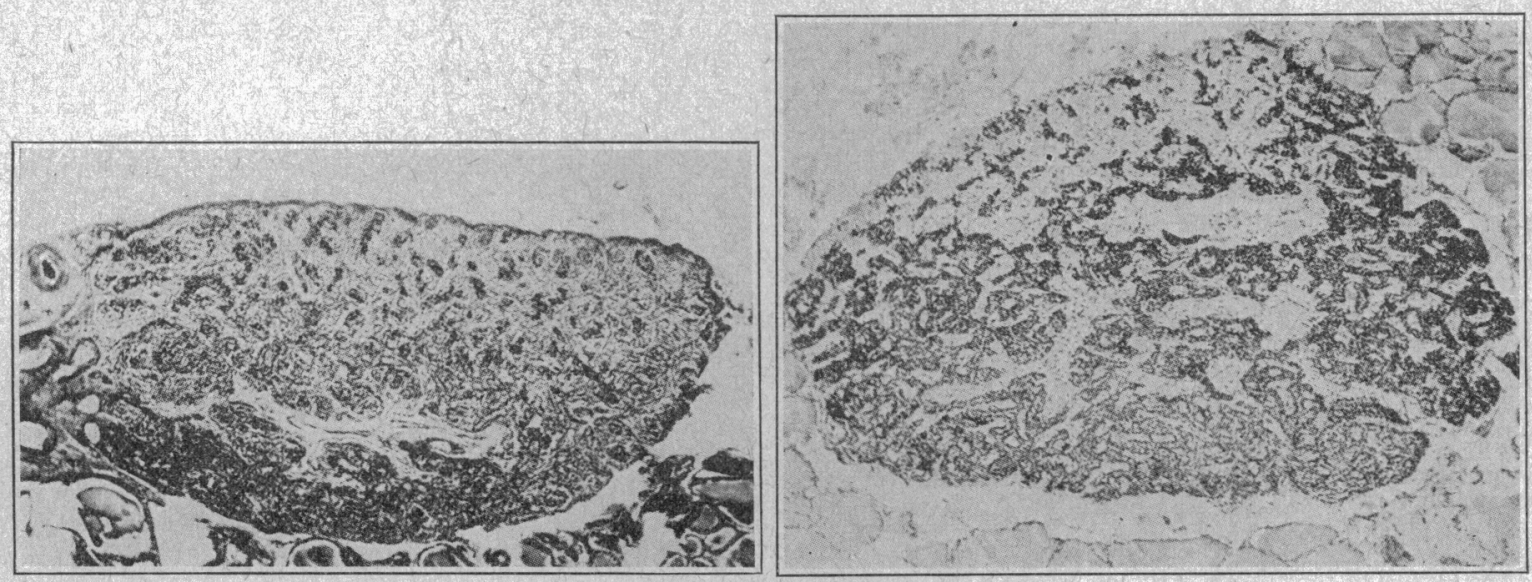

C

FIG. 1.

Sections through the parathyroid glands of dogs to show the normal structure, $\mathbf{A}$, and the different degrees of alteration following hypophysectomy, namely, slight modification, B; medium, $\mathrm{C}$; and intense, $\mathrm{D}$.

(b) Medium: large groups of closely packed nuclei, disappearance of numerous cells, trabeculae of cord-like structure.

(c) Intense: numerous groups of closely packed nuclei, disappearance of many cells, cordlike structure, thick connective tissue trabeculae. (Figure 2B.)

(d) Very intense: -numerous groups of closely packed nuclei, large fields without cells, cord-like structure, abundant connective tissue, numerous and large blood vessels. (Figure 2C.)

The lesion consists of a simple, progressive atrophy of the cells, with pyknosis and slow disintegration of nuclei. The decrease and retraction of the parenchyma make the connective tissue become more apparent. There is no reduction in the blood supply, on the contrary the blood vessels are large and numerous. There is no granular, fatty or colloidal degeneration. There are no signs of compensatory hyperplasia. The most characteristic features are the global atrophy with darkening of the proto- plasm, the accumulation of nuclei (in 66 per cent), the structureless zones, and the great irregularity of the lesions which leave large parts of the gland with little or no alterations. This last fact explains why these animals do not have hypocalcemia. To interpret these lesions it is necessary to examine many cases, make numerous sections of each gland and acquire experience in the study of this tissue. If a careful examination is not made, characteristic lesions, obvious to a skilled observer, may be passed over.

In our series of dogs the following alterations were found:

\begin{tabular}{|c|c|c|c|c|c|c|c|}
\hline & 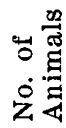 & $\begin{array}{l}\overrightarrow{7} \\
\overrightarrow{000} \\
\overrightarrow{0}\end{array}$ & 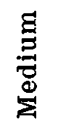 & $\begin{array}{l}\Phi \\
\stackrel{\Xi}{\Xi} \\
\stackrel{\Xi}{\Xi} \\
\stackrel{\Xi}{\Xi}\end{array}$ & 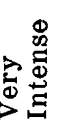 & 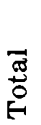 & $\begin{array}{l}\overrightarrow{0} \\
\circlearrowright \\
\vdots \\
\dot{0} \\
0\end{array}$ \\
\hline & 4 & 4 & - & - & 二 & 4 & \\
\hline yse & & 16 & 10 & $\overline{-}$ & & 30 & 100 \\
\hline ith tuber & 16 & $\overline{3}$ & $\begin{array}{l}2 \\
3\end{array}$ & 二 & 1 & $\begin{array}{l}3 \\
6\end{array}$ & $\begin{array}{r}100 \\
37\end{array}$ \\
\hline
\end{tabular}

We have not been able to counteract these effects by the administration of anterior pitui- 


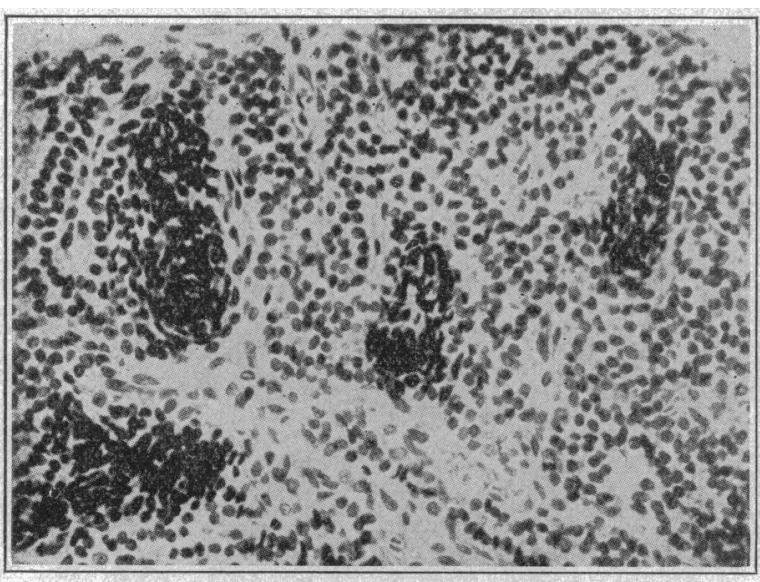

A.

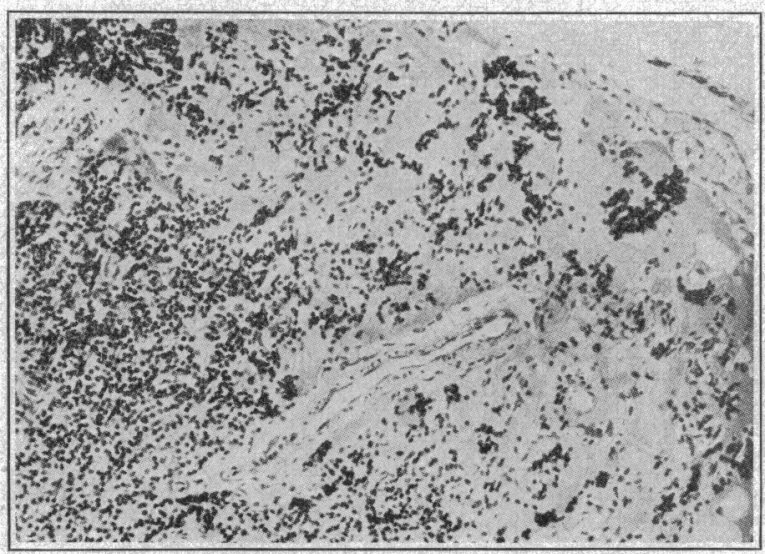

B

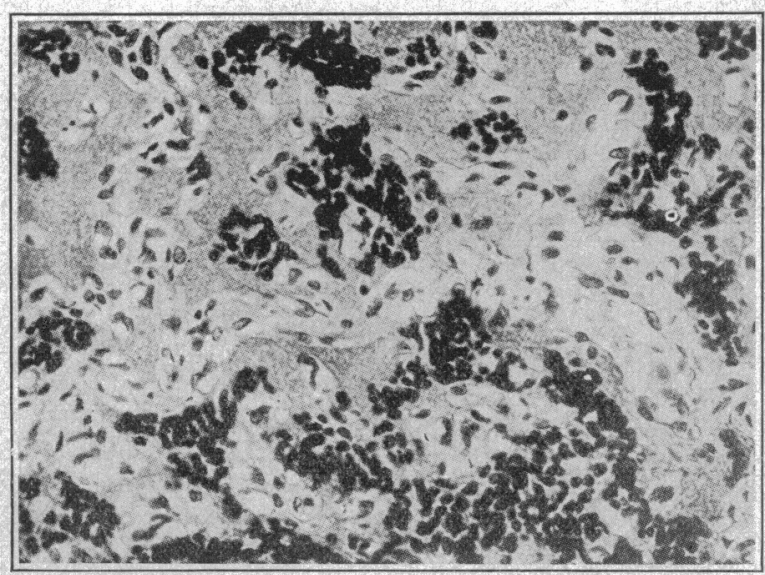

C

FIG. :.

Sections through the parathyroids of hypophysectomized dogs showing, A, syncytium-like groupings of cells; $B$, acellular zones; and $\mathrm{C}$, combined syncytium-like grouping and acellular zones. tary lobe extract, though it has been tried in many cases. It is possible that the doses employed were not sufficient or that the activity of the extract was inadequate.

Calcemia. In spite of the lesions in the parathyroids the plasma calcium was normal in the forty-seven hypophysectomized dogs so far studied in our Institute, ${ }^{26,41,56,57,60 *}$ the average being $10.67 \mathrm{Mgm}$. per $100 \mathrm{cc}$. in the operated and $10.7 \mathrm{Mgm}$. per $100 \mathrm{cc}$. in the controls. In rats also normal values have been found. ${ }^{17,84}$ In two pigeons there was a slight decrease. ${ }^{71}$ In rabbits hypophysectomy is followed by a slight increase, ${ }^{50}$ but irradiation of the pituitary sufficient to damage the gland does not alter the blood calcium. ${ }^{10}$ The toad Xenopus levis has a low blood calcium after extirpation of the principal lobe of the pituitary ${ }^{13,35,78}$ and after gonadectomy.

Parathyroid extract increases the blood calcium of hypophysectomized rats $^{76}$ and pigeons ${ }^{71}$ to the same degree as it does in normal controls. It also produces a similar proliferation of osteoblasts and new bone formation in hypophysectomized rats as in normal controls. ${ }^{76}$ Hypophysectomized rats, however, show a tendency to a negative calcium balance, which is counteracted by growth-promoting pituitary extract. ${ }^{68}$ On the other hand, the thyrotropic extract ${ }^{24,68}$ and thyroid administration increase the fecal excretion of calcium with the rise in the total metabolism.

\section{THE PARATHYROIDS IN HYPERPITUITARISM}

Parathyrotropic action of anterior pituitary $e x$ tract. Anselmino, Hoffmann and Herold ${ }^{3}$ have shown that anterior pituitary extract produces a considerable enlargement of the parathyroids in rats. There is hyperemia, increase in the number and size of the clear cells, decrease of the dark cells and disappearance of oxyphilic cells. $\dagger$ The same effect is obtained with the alcoholic precipitate of pregnancy urine, which has no thyrotropic activity. Hypertrophy and hyperplasia of the parathyroids have also been obtained in rabbits by the injection of pregnancy urine (Hertz and Kranes, 1934). We have seen this occur in less than half of the dogs injected with anterior pituitary extract (1.4 $\mathrm{Gm}$. per Kgm. per diem of fresh bovine anterior lobe for one week). An increase of the blood calcium lasting several hours has been observed in the dogs injected with this extract, but it does not occur if the thyroids and parathyroids have been removed. ${ }^{3,34,56,57,83 \ddagger}$ The *In two hypophysectomized dogs Koster and Geesink ${ }^{\mathbf{4 7}}$ found a Iower blood calcium than in their control animals. Since the values in the latter were 13 to $14.2 \mathrm{Mgm}$. per $100 \mathrm{cc}$. the observations are hardly significant. Nishida ${ }^{63}$ found $10.41 \mathrm{Mgm}$. in hypophysectomized dogs and $9.97 \mathrm{Mgm}$. per $100 \mathrm{cc}$. in the controls.

†Anselmino and Hoffmann have had the kindness to send me their microscopical preparations.

+This has also been found in the catiz and in Xenopus levis is but in the rat there is no rise in the blood calcium following this treatment. 
parathyrotropic factor has not been completely separated from other hormones but it is known that it is not ultrafiltrable and that it is destroyed by boiling.

The gonadotropic extract aggravates tetany and decreases the blood calcium of thyro-parathyroidectomized bitches, due to the increased secretion of estrin. ${ }^{59}$

Hyperparathyroidism. In seventeen out of 101 published cases of hyperparathyroidism an enlargement of more than one of the parathyroids has been reported. This fact has led to the belief that a stimulating action of the anterior pituitary may be a factor in the etiology of these cases. ${ }^{1}$ Of special significance is the finding by Hertz and Albright ${ }^{30}$ that the injection of urine from patients with multiple parathyroid hyperplasia is capable of producing parathyroid hyperplasia in rabbits. Urine injection from cases of parathyroid adenoma does not produce this change.

Human hyperpituitarism. In cases of acromegaly some observers have seen enlargement $^{5,15,25,70}$ or adenomas ${ }^{12,21,27,45}$ of the parathyroids. Cushing and Davidoff ${ }^{21}$ noted a marked proliferative activity in one case and parathyroid adenomas in two others. In various postmortem examinations of acromegalics, abnormalities of the parathyroids have been reported. In one curious case of chromophobe adenoma of the pituitary, Lloyd ${ }^{54}$ found a simultaneous enlargement of the parathyroids and of the islets of Langerhans. In Cushing's disease cervico-dorsal kyphosis forms part of the syndrome. Osteoporosis and decalcificatiois have been reported in fourteen out of twentyfour cases with postmortem examination in the literature. In nine of the fourteen cases collected by Cushing $^{20}$ there were spontaneous fractures, and osteomalacia was present in six.

The condition of the parathyroids is mentioned in fourteen of the twenty-four cases which we have found reported with a postmortem examination: in three cases there was an adenoma, ${ }^{33,51,62,75}$ in three the glands were enlarged, ${ }^{20}, 49,60$ in six they were normal, ${ }^{2,16,19,}$ ${ }^{65,73}$ and in one they were atrophied. ${ }^{82}$ Lipomatosis associated with other lesions was present in three of these cases and unassociated with other lesions in twenty others. ${ }^{20,49,51,69,72,74,82}$

Cushing ${ }^{20}$ believes that the basophile adenoma of the pituitary produces a state of hyperparathyroidism which in its turn causes the bone lesions; Hoff, ${ }^{33}$ on the other hand, thinks that in his case the pituitary adenoma was secondary to the hyperparathyroidism. Cushing's opinion meets with various objections : in most of the cases studied up to now lesions due to parathyroid hyperfunction have not been demonstrated; the bony lesions differ from those of hyperparathyroidism; similar bony lesions have been found in cases of primary hyperinterrenalism; the blood calcium and inorganic phosphorus have been found to be normal, or the calcium slightly diminished and the phosphorus slightly increased. $6,7,9,32,43,46,51,74,81$ The negative calcium balance, observed by Aub in one of Cushing's cases, is common to various bone diseases. ${ }^{6}$

In one of Cushing's cases Aub observed a marked amelioration of all symptoms, including those related to the skeletal system, following irradiation of the hypophyseal region. The negative calcium balance was also diminished.

\section{THE PITUITARY AND PARATHYROID TETANY}

Caselli, in 1900, reported that extirpation of the pituitary in dogs suffering from tetany due to parathyroid insufficiency caused a more rapid death without alteration of the symptoms. We removed the thyroids and parathyroids in eight hypophysectomized dogs and found that they developed tetany and died similarly to normal dogs which were thyro-parathyroidectomized.

Extract of the whole pituitary gland or of the posterior pituitary can transitorily calm the tetany ${ }^{11,36,40,64,65}$ after an initial exacerbation of the symptoms. The mechanism of this action is not clear, since these extracts do not prevent the reappearance of attacks of tetany or the lethal termination of the condition. We could neither prevent nor cure tetany in thyroparathyroidectomized dogs, nor prevent the fall in blood calcium, by injecting large doses of an alkaline pituitary extract intraperitoneally for two to three days before or after the onset of tetany.

\section{THE PARATHYROIDS IN PANCREATIC INSUFFICIENCY}

Morphology. With R. Sammartino, we have studied the parathyroids of twenty-nine totally pancreatectomized and eight partially pancreatectomized dogs. After one to three days with no insulin the cells of the parathyroids become vacuolated and appear large and clear. (Figure 3.) The vacuoles appear first near the connective tissue trabeculae, following which they increase in size and coalesce. Later the protoplasm liquefies and disintegrates, the nuclei come closer together and form rows contiguous to the trabeculae, and the gland assumes a tubular aspect. In some cells there are also nuclear changes.

When the condition is more intense, the gland decreases in size and presents either an insular or a cord-like structure, due to the decrease in the volume of the cells and the approximation of the nuclei to each other. Some of the latter become pyknotic.

These lesions occur early, are intense, and affect the whole gland. (Figure 4.) The syn- 


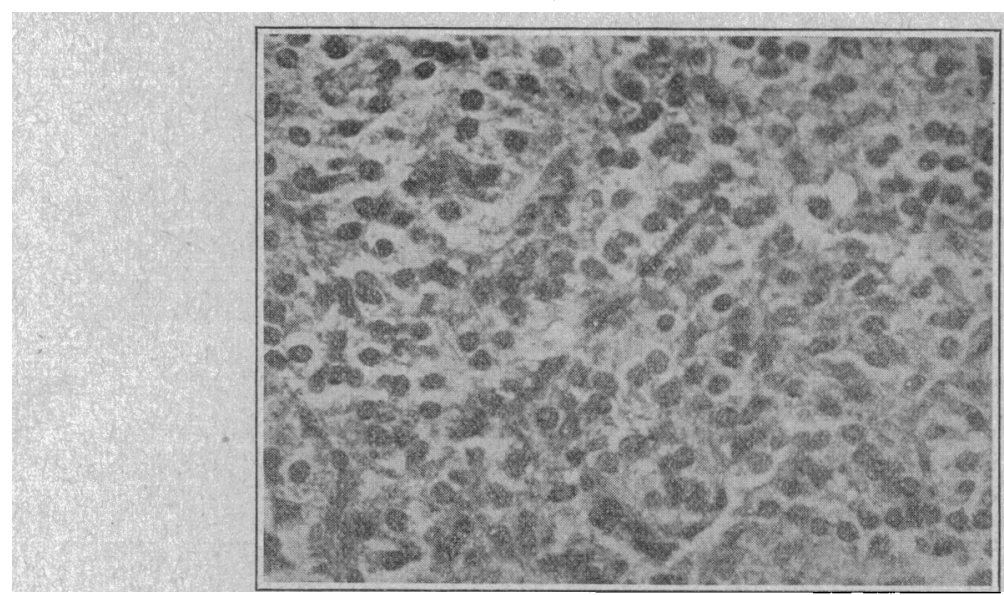

$A$

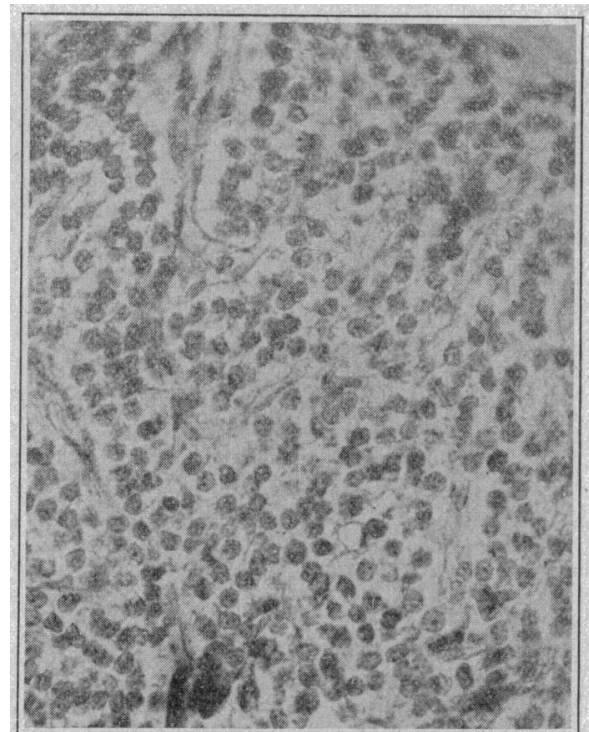

B

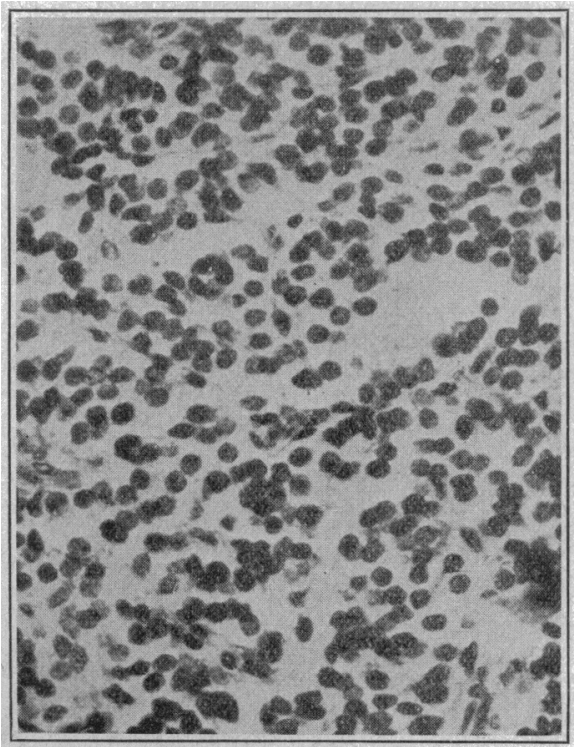

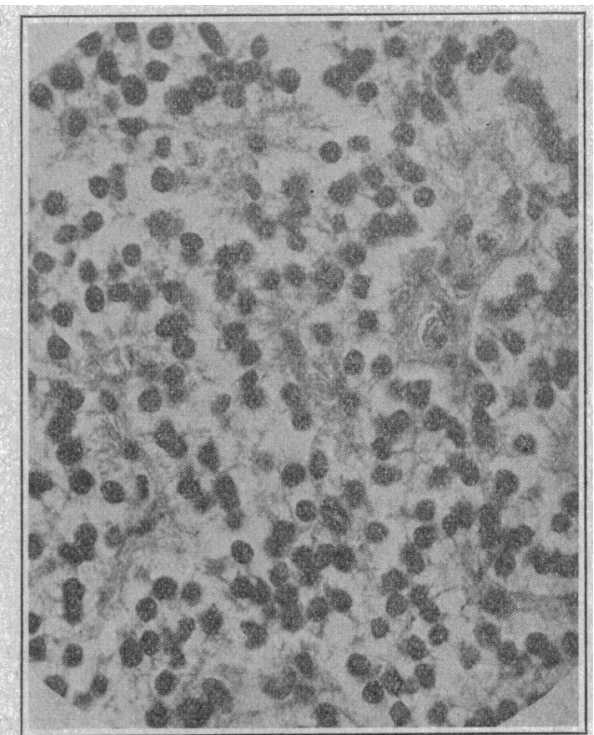

C

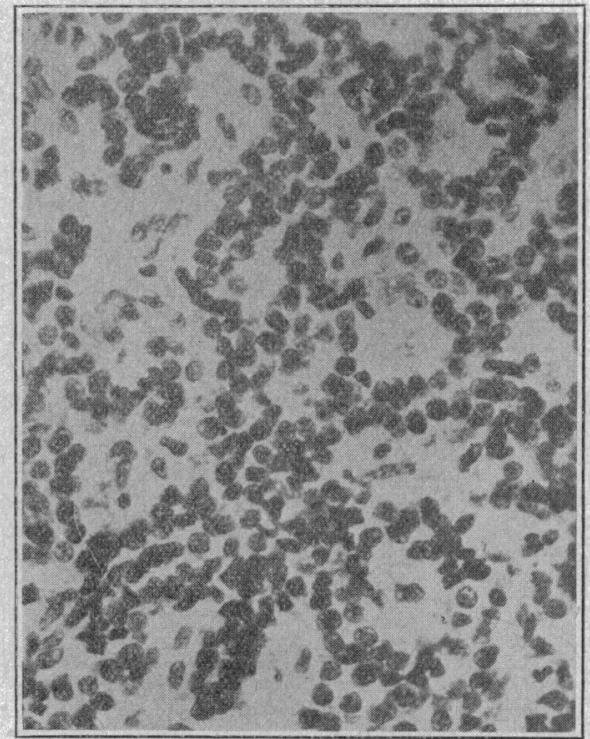

$\mathbf{E}$

FIG. 3.

Sections thlough the parathyroid glands of dogs showing $A$, the normal cytological structure and, B, C, D and E, the progessive stages in the vacuolization and protoplasmic liquefaction which follows pancreatectomy. 


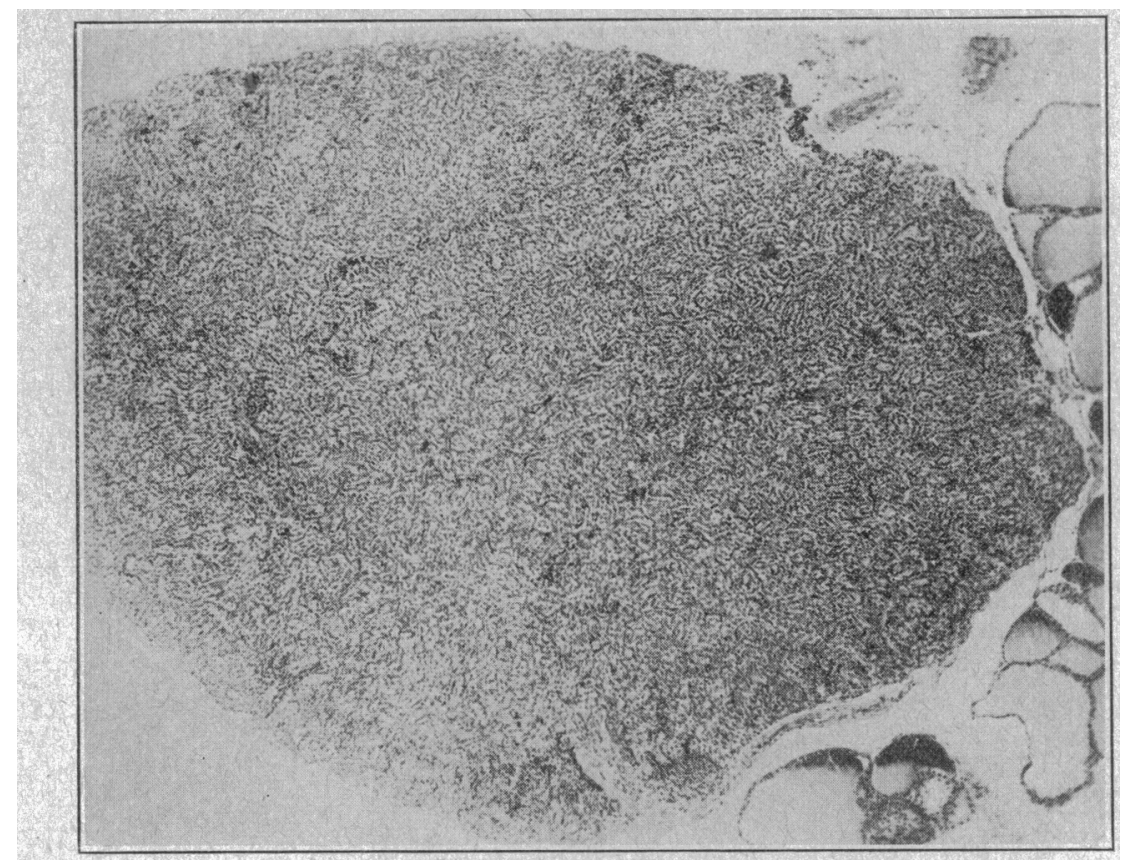

A

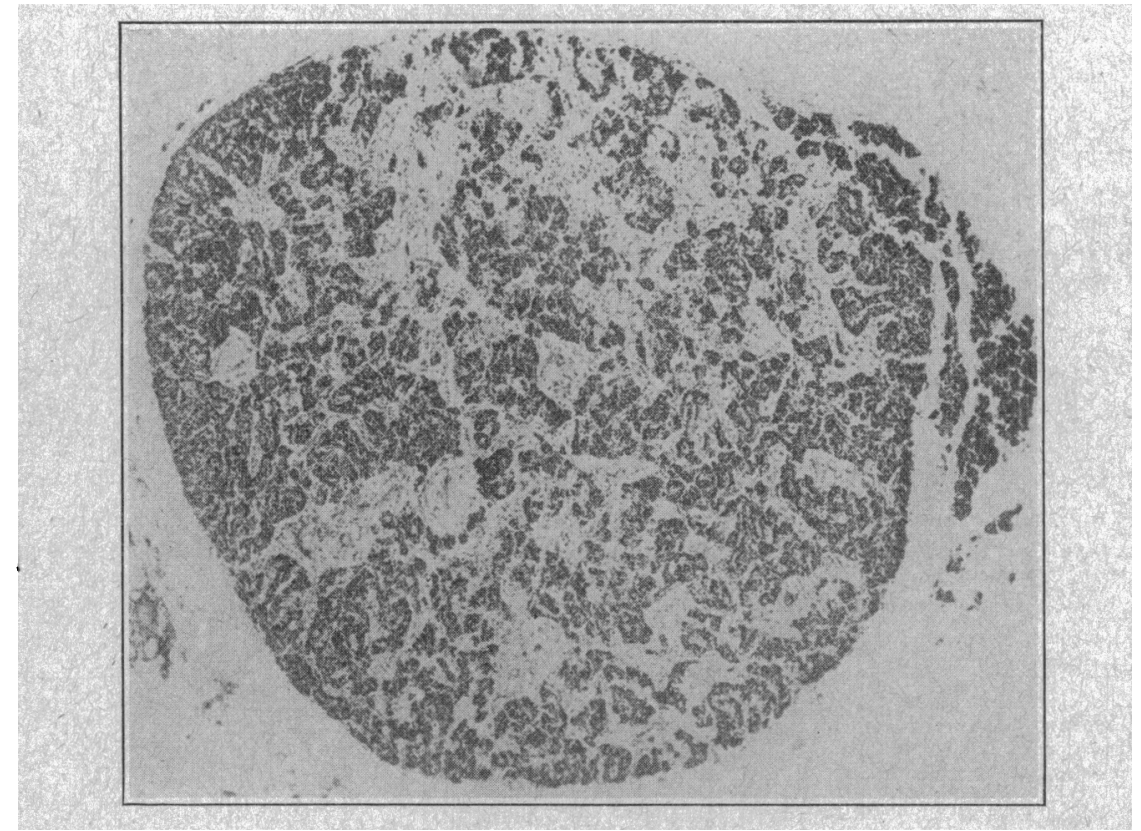

$\mathrm{B}$

FIG. 4.

Sections through the parathyroid glands of dogs.

A. Normal.

b. Following nancreatectomy, showing the insular and cordlike structure.

cytium-like accumulations which occur frequently in hypophysectomized animals (66 per cent) are as infrequent in the pancreatectomized (two out of twenty-nine) as in the normals (10 per cent). In contrast with the hypophysectomized animals, where there is a global atrophy of the cells, in the pancreatectomized there is vacuolization and disintegration of the protoplasm.
Calcemia. The determinations made in our Institute on forty pancreatectomized dogs by Marenzi and Gerschman ${ }^{5 \pi}, 58$ show that blood calcium decreases from the normal level of 10 11.5 $\mathrm{Mgm}$. per 100 ce. of plasma to 8.2-10.5 Mgm. in four days and to 7.3-9.6 $\mathrm{Mgm}$. in seven days. Determinations on twelve dogs showed that in two it fell to 9.2-9.3, in six to 8.1-8.8 and 


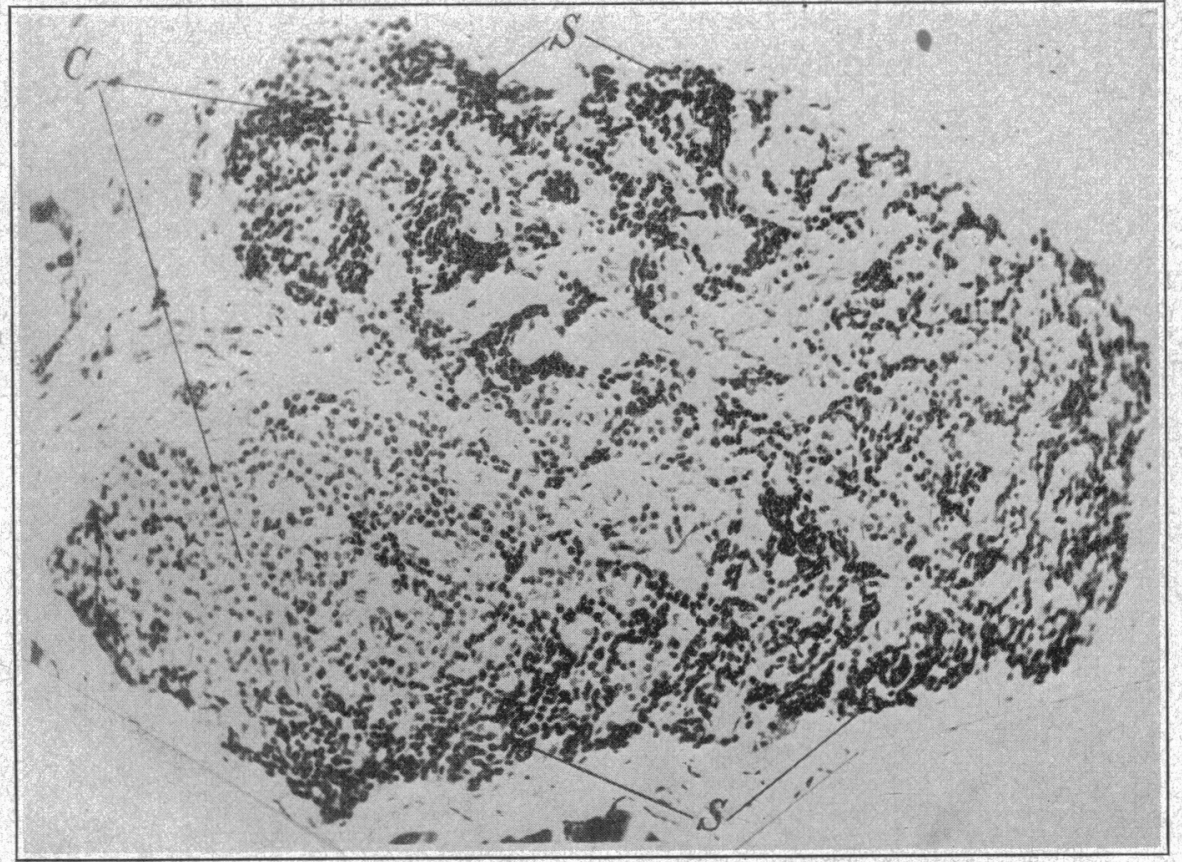

A

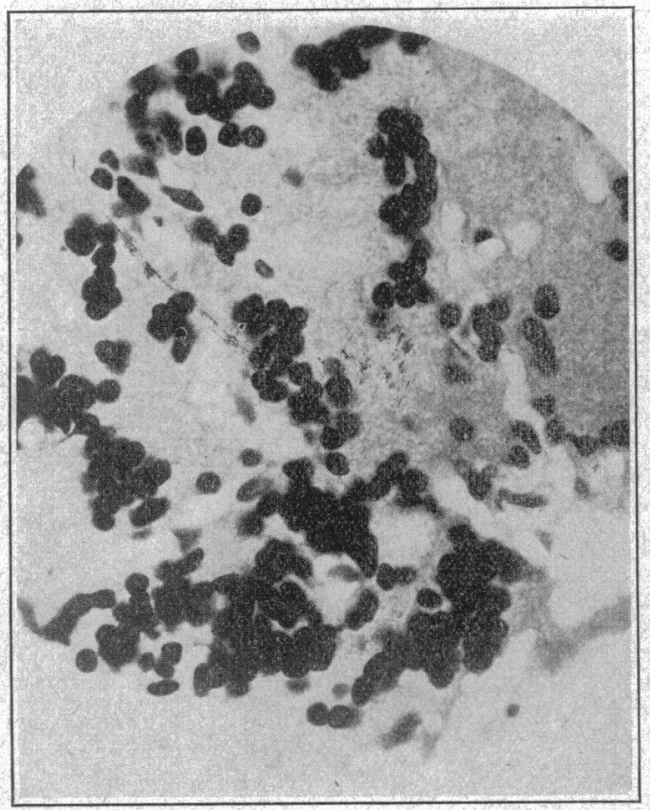

B

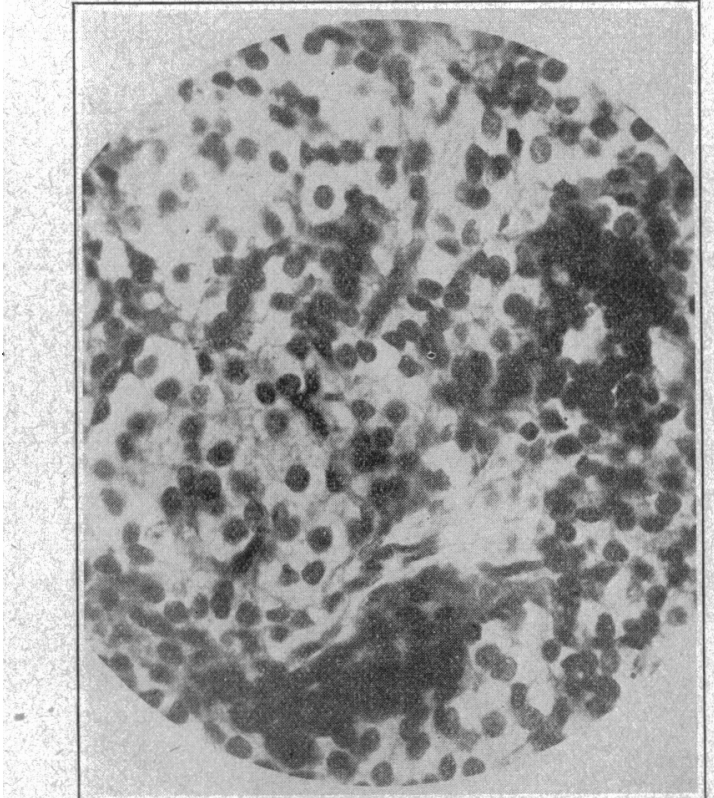

C

FIG. 5 .

Sections through the parathyroids of hypophysectomizedpancreatectomized dogs.

A. Low magnification, showing the general structure: at $S$ there are atrophic zones and syncytium-like groupings of cells; at $C$ occur areas of vacuolated and clear cells.

B. Higher magnification, showing the acellular zones and syncytium-like groupings.

C. Magnification as in B, showing clear and vacuolated cells. 
in four to $7.3-7.6$, the average being $8.2 \mathrm{Mgm}$. per 100 ec. plasma. The decrease in blood calcium depends on the intensity of the diabetes and is less marked and occurs more slowly or may even be absent if the pancreatectomy is subtotal.

There is also an increase in the inorganic phosphorus which may reach $14 \mathrm{Mgm}$. per 100 ce. of plasma (the average is $8.8 \mathrm{Mgm}$.), and a decrease in the sodium and chlorides, the alkaline reserve and the total $\mathrm{CO}_{2}$ (average 31.9 ec.).

Treatment with insulin prevents the decrease in blood calcium or causes it to rise if already diminished. We did not, however, obtain a return to the original level in our experiments, nor did the histological appearance of the parathyroid glands become normal. This was probably due to the fact that the blood sugar remained elevated and the glycosuria did not completely disappear.

The injection of parathormone caused a rise in the blood calcium (up to $15 \mathrm{Mgm}$. in one case), just as in normal dogs.

Extract of anterior pituitary lobe was injected into the pancreatectomized animals, but it resulted in an intensification of the diabetes leading to coma and death in one to two days, with a marked hypocalcemia (averaging about $7 \mathrm{Mgm}$. and in one case falling to $3.9 \mathrm{Mgm}$. per 100 ec. plasma).

The hypocalcemia and the changes in the parathyroids do not occur in dogs with intact pancreas under conditions of simple fasting, or after the administration of phlorhizin for a week either during fasting or with feeding, even though there is intense glycosuria and loss of weight.

Human diabetes. Kraus ${ }^{48}$ has observed parathyroid lesions in some young diabetics, the principal cells being poor in protoplasm, with dark nuclei, giving the appearance of lymphoid tissue. These are the cytological signs of atrophy and functional insufficiency. In adults there is less cellular alteration. According to Jansen $^{44}$ the blood calcium is normal in diabetics except in certain isolated cases which have ketonuria. In these it may fall to $8.2-8.5 \mathrm{Mgm}$. per 100 cc. (as compared with $11.5 \mathrm{Mgm}$. in normals). He attributes this fall to a loss of caleium in the feces due to the acidosis.

It is premature to attempt to connect the arteritis, cataracts, bony alterations, etc., of diabetics with an alteration in the calcium metabolism and parathyroid dysfunction.

\section{THE PARATHYROIDS IN HYPOPHYSECTOMIZED-} PANCREATECTOMIZED ANIMALS

Morphology. We found with Sammartino that the parathyroids in nine hypophysectomized-pancreatectomized animals presented both the lesions found in hypophysectomized and those seen in pancreatectomized animals separately (figure 5). In six such preparations there were abundant syncytium-like groups of cells and structureless, degenerated basophilic zones. At the same time in extensive areas, sometimes occupying the whole gland, there was vacuolization of the cells, the latter becoming big, and vesicular, with transparent protoplasm. This is the appearance of the parathyroid in the early stages after pancreatectomy, and probably the lesions do not develop further as the diabetes is not so intense in the hypophysectomized-pancreatectomized animals.

Calcemia. The calcemia of these animals is lowered as in the pancreatectomized, but the fall occurs more rapidly. Thus, in eight cases after four days, Marenzi and Gerschman ${ }^{57,58}$ found blood ealciums of $8.10,7.6,8.6,9.2$ and $7.5 \mathrm{Mgm}$. (average $8 \mathrm{Mgm}$.) per $100 \mathrm{ce}$. The inorganic phosphorus rises less (average 5.7 Mgm.) than in the pancreatectomized animals; the alkaline reserve does not change greatly (average 54); the sodium and chlorides decrease, and, because of the hypophysectomy, blood potassium also falls.

\section{GENERAL SUMMARY}

In the presence of pituitary insufficiency in the dog there is cellular atrophy in the parathyroids with foci or zones of accumulated nuclei, which simulate cords, and occasionally acellular, basophilic areas. These changes may be the result of general nutritive alterations or of the lack of parathyrotropic hormone.

The blood calcium is not altered, probably because the parathyroid lesion is partial or incomplete.

Anterior pituitary extract increases the size of the parathyroids and their content of clear cells. It also raises the blood calcium; but this rise does not occur when the parathyroids have been removed.

The theory has been put forward that an excess of parathyrotropic hormone may be the cause of human hyperparathyroidism but more observations are necessary for confirmation.

The state of the parathyroids in hyperpituitarism has not been studied carefully in large series of cases. Adenomas have been found in cases of acromegaly, and adenomas or enlargement in some cases with Cushing's syndrome, but in general the parathyroids are normal or lipomatous in these diseases. Whether the origin of the osteoporosis in Cushing's syndrome is due to hyperparathyroidism or to the adrenals or to some other cause is not certain.

Pituitary extracts do not prevent or cure the hypocalcemia and tetany due to parathyroidectomy and the results following thyro-parathyroidectomy are similar in hypophysectomized and in normal dogs. 
In pancreatic insufficiency in the dog there is vacuolization, liquefaction and later protoplasmic disintegration of the cells of the parathyroids. The nuclei remain isolated, forming tubes, rows or islets. In three to seven days the blood calcium is lowered to levels between 7 and $9 \mathrm{Mgm}$. per $100 \mathrm{cc}$. of plasma and the blood phosphorus increases. Insulin prevents the decrease of the blood calcium, but, in experiments at our Institute, late treatment with insulin, after the fall in calcium had occurred, was not completely effective in raising it to normal, nor was the normal histological appearance of the glands restored. It should be noted, however, that in these experiments overnight hyperglycemia was not controlled and further observations are therefore necessary.

In hypophysectomized-pancreatectomized dogs the lesions due both to hypophysectomy, and to pancreatectomy occur side by side. The lesions due to pancreatectomy are not so severe as in dogs in which the pancreas alone has been removed though the hypocalcemia is similar in the two groups.

The proper functioning of both the pituitary and pancreas is necessary in order to maintain the integrity of the parathyroids. Insufficiency of one or the other of these glands results in different changes. Although proof for the theory is incomplete it may be suggested that in hypophysectomized animals there is a lack of a parathyrotropic hormone, which may or may not be a specific one; whereas, in the pancreatectomized animals, the changes may be due to nutritive disturbances associated with the diabetic condition.

\section{REFERENCES}

1. Albright, F.; Bloomberg, E.; Castleman, B., and Churchill, E. D.: Arch. Int. Med. 64:315 (Sept.) 1934

2. Anderson, J.: Glasgow M. J. 83:178, 1915.

3. Anselmino, K. J.; Hoffmann, F., and Herold, L.: Klin. Wchnschr. 12:1944 (Dec. 16) 1933; 13:45, 1934.

4. Aschner, B.: Arch. f. d. ges. Physiol. 146:1, 1912

5. Bartlett. F. K.: Arch. Int. Med. 12:201, 1913 .

6. Bauer, J.: Klin. Wchnschr. 14:361 (March 16) 1935.

7. Bengolea, A. J., and Martinez de Hoz, R.: Rev. méd, quir. Patol. Femen. (Bs. As.) 2:340, 1934.

8. Berblinger, W.: Hirsch. Handb. inn. Sekr. 1:910, 1932.

9. Buchem, F. S. P. van: Ztschr. f. klin. Med. 127:292, 1934.

10. Cannavo, L., and Beninato, R.: Endokrinol. 15:389, 1935.

11. Carlson, A.' J., and Jacobson, C.: Am. J. Physiol. 28:133, 1911.

12. Carnot, P.: Rathery, A., and Dumont, J.: Bull. Soc. méd hôp. $35: 921,1913$

13. Charles, E.: Proc. Roy. Soc. Med. 107:504, 1931.

14. Cimoroni, A.: Arch. ital. de biol. $48: 387,1907$.

15. Claude, H., and Baudouin, A.: Compt. rend. Soc. de biol. $71: 75,1911$.

16. Close, H. G.: Brit. M. J. 1:356 (Feb.) 1935.

17. Collip, J. B.: J. Mt. Sinal Hosp. 1:28 (May-June) 1934

17. Collip, J. B.: J. Mt. Sinai Hosp. 1:28 (May-June)
18. Collip, J. B.: J. A. M. A. 104:916 (March 9) 1935.

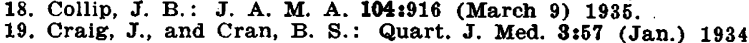

20. Cushing, H.: Arch. Int. Med. 61:487 (April) 1933

21. Cushing, H., and Davidoff, L. M.: Monograph 22, Rockefeller Inst. Med. Research, New York, 1927.

22. Danisch, F': Frankfurt. Ztschr. f. Path. 38:290, 1929.

23. Dixon, T. F.: Biochem, J. 27:410, 1933.

24. Eggs, F.: Deutsch. Ztschr. Chir. 242:321, 1934.

25. Erdheim, J.: Beitr. z. path. u. z. Allg. Path. 33:158, 1903.

26. Gerschman, R.: Rev. Soc. argent. de biol. $7: 302,1931$; Compt. rend. Soc. de biol. 108:494 (Oct. 30) 1931 .

27. Gilbert-Ballet and Laignel-Lavastine: Rev. neurol. 12:793, 1904.

28. Herring, P. T.: Quart. J. Exper. Physiol. 1:281, 1908.
29. Herring, P. T.: Proc. Roy. Soc. Med. 92:102, 1921.

30. Hertz, S., and Albright, F.: Tr. A. Am. Physicians, May, 1934, quoted by Collip.

31. Hertz, S., and Kranes, A.: Endocrinol. 18:350, 1934; Arch. Path. 18:589, 1934 .

32. Hildebrand, K. H.: Klin. Wchnschr. 14:951 (July 6) 1935

33. Hoff, F.: Verhandl. d. deutsch. Geselisch. f. inn. Med. Kong. $46: 441,1934$.

34. Hoffmann, F., and Anselmino, K. J.: Kḷin. Wchnschr. 13:44 (Jan. 13) 1934 .

35. Hogben, L.; Charles, E., and Slome, D.: J. Exper. Biol. $8: 345,1931$.

36. Houssay, B. A.: La accion fisiologica de los extractos hipofisarios, 1918-20. Bs. As., Flaiban.

37. Houssay, B, A and Biasotti, A.; Rev. Soc argent de biol. $6.251,1930$; Compt. rend. Soc. de biol. $105: 121,124,1930$; $6: 251,1930$; Compt. rend. Soc. de biol.
Pflügers Arch. ges. Phys. $227: 664,1931$.

38. Houssay, B. A.; Biasotti, A., and Lascano Gonzalez, J. M. : Congr. Intern. Biol. Montevideo Oct., 1930; Arch. Soc. Biol. Montevideo, 1931 , supp., fasc. 2,479 .

39. Houssay, B. A.; Biasotti, A., and Lascano Gonzalez, J. M. : Arch. Soc. Biol. Montevideo, 1931, supp., fasc. 2, 479.

40. Houssay, B. A.: Semana méd. 23:559 (Nov.) 1916 .

41. Houssay, B. A., and Mazzocco, P.: Rev. Asoc. med. argent. 34:1165 (Nov.) 1921; (Soc. Biol. 2:327); Compt. rend. Soc. de biol. 86:409, 1922 .

42. Houssay, B. A., and Sammartino, R.: Rev. Soc. argent. de biol. 9:236 (July) 1933; Compt. rend. Soc. de biol. 114:729, 1933 ; Beitr. z. Path. Anat. 93:405, 1934.

43. Hoyle, C.: Proc. Roy. Soc. Med. 27:395 (Part I) 1933-34.

44. Jansen, W. H.: Deutsches Arch. f. klin. Med. 144:14 (April)

1924 .
45. Josephson, A.: Om endokrina skelet-och utvecklingsrubbningar, Stockholm, A. Marcus, quoted by Cushing, Davidoff.
.

46. Kepler, C. J.; Kennedy, R. L.; Davis, A. C.; Walters, W and Wilder, R. M.: Proc. Staff. Meet. Mayo Clin. 9:169 (March) 1934 .

47. Koster, S., and Geesink, A.: Arch. neerl. de physiol. 13:60, 1928.

48. Kraus, E. J.: Virchows Arch. f. path. Anat. $247: 1,1923-24$

49. Kraus, E. J.: Med. Klin. 20:1290, 1328, 1924

50. Kusunoki, G.: Folia. endocrin. japon. 3:34 (Dec. 22) 1927.

51. Lawrence, J. H., and Zimmerman, H. M.: Arch. Int. Med $55: 745,1935$.

52. Leriche, R., and Jung, A.: Presse med. 14:265 (Feb.) 1933.

53. Livon, C., and Peyron: Compt. rend. Soc. de biol. 71:49, 1911

4. Lloyd, P. C.: Bull. Johns Hopkins Hosp. 46:1 (July) 1929

55. Marburg, $O$.: Arb. a. d. neurol. Inst. a. d. Wien. Univ. $85: 143,1933$.

56. Marenzi, A. D., and Gerschman, R. Rev. Soc. argent. de biol. 10:131, 1934; Compt. rend. Soc. de biol. 117:56, 1934

57. Marenzi, A. D., and Gerschman; R.: Rev. Soc. argent. de biol. Sujp. fasc. 10:350, 1934; Compt. rend. Soc. de biol. $117: 56,1934 ; 118: 488,1935$

58. Marenzi, A. D., and Gerschman, R.: Rev. Soc. argent. de biol., 1935 (in press); Compt. rend. Soc. de biol. (in press).

59. Mathieu, F.: Compt. rend. Soc. de biel. 113:903, 1933.

60. Mazzocej, P.: Rev. Soc. argent. de biol. 3:213, 1927; Compt. rend. Soc. de biol. $97: 594,1927$.

61. Mitchell, J. B., Jr.: Anat. Rec. 41:25, 1928-29; Physiol. Zoöl. 2:411 (July) 1929.

62. Molineus: Arch. f. klin. Chir, 101:333, 1913

63. Nishida, S.: Jap. J. M. Sc., Tr. IV, Pharmacol. 8:83 (Aug.)

1934.
64. Ott, I., and Scott, J. C.: New York M. J. 88:1180, 1908; $89: 359$, 1909; Internal Secretion, 1910, Vogel.

65. Pal, J.: Deutsche med. Wchnschr. 41:1537 (Dec.) 1915.

66. Poos, F : Klin. Wchnschr. 6:1884 (Oct.) 1927 .

67. Pugsley, L. I.: J. Biol. Chem. 100:LXXXI (May) 1933.

68. Pugsley, L. I., and Anderson, E. M.: Am. J. Physiol. $109: 85,1934$

69. Raab, W. : Wien. Arch. f. inn. Med. 7:443 (March) 1924

70. Reinhardt, A., and Creutzfeldt, H. G. : Beitr, z. path. Anat. u. z. allg. Path. 56:465, 1913.

71. Riddle, O., and Dotti, L. B.: Proc. Soc. Exper. Biol. \& Med. 32:507 (Dec.) 1934.

72. Roch, M.: Presse méd. 42:987 (June) 1934

73. Rusisell, D. S.; Evans, $H$., and Crooke, A. C.: Lancet $2: 240$ (Aug. 4) 1934.

74. Rutishauser, E.: Deutsches Arch. f. klin. Med. 175:640, 1933.

75. Schmorl, G.: München. med. Wchnschr. 59: (Part 2) 2891 1912.

76. Selye, H. ; Mortimer, H. ; Thomson, D. L., and Collip, J. B.: Arch. Path. 18:878, 1934 .

77. Shapiro, H. A.: Quart. J. Pharm. \& Pharmacol. 7:223 (April-June) 1934 .

78. Shapiro, H. A., and Zwarenstein, H. J.: Exper. Biol. 10:186 (April) 1933; 11:267 (July) 1934.

79. Smith, P. E.: Am. Anat. Mem. No. 11:97, 1920. Wistar Inst. Pa.

80. Smith, P. E.: J. A. M. A. 88:158 (Jan.) 1927.

81. Sokolow, D., and Gromow, L.: Vestnik Endokrinologie 4:411, 1934 .

82. Swan, W. G. A., and Stephenson, G. E.: Lancet 1:372 (Feb. 16) 1935

83. Thompson, K. W., and Cushing, H.: Proc. Roy. Soc, London, $115: 88$ (May) 1934 .

84. Wallace, E. W.: J. Pharmacol. \& Exper. Therap. (Ser. B) $64: 161,1935$.

85. White, W. E.: Proc. Roy. Soc. Med. 114:64, 1933. 